\title{
Protective action of taurine, given as a pretreatment or as a posttreatment, against endotoxin-induced acute lung inflammation in hamsters
}

\author{
Tapan M Bhavsar ${ }^{\dagger}$, Sanket N Patel ${ }^{\dagger}$, Cesar A Lau-Cam* \\ From $17^{\text {th }}$ International Meeting of Taurine \\ Fort Lauderdale, FL, USA. 14-19 December 2009
}

\begin{abstract}
To assess the effect of taurine on lipopolysaccharide (LPS)-induced lung inflammation, oxidative stress and apoptosis, female Golden Syrian hamsters were intratracheally instilled with bacterial LPS (0.02 mg in phosphate buffered saline (PBS) pH 7.4), before or after a 3-day intraperitoneal treatment with a single dose of taurine $(50 \mathrm{mg} / \mathrm{kg} /$ day in PBS pH 7.4), and bronchoalveolar lavage fluid (BALF) and lung tissue samples were collected at $24 \mathrm{hr}$ after the last treatment. In comparison to BALF samples from animals receiving only PBS pH 7.4, and serving as controls, those of LPS-stimulated animals exhibited a higher count of both total leukocytes and neutrophils and increased expression of tumor necrosis factor receptor 1. In comparison to lungs from control animals, those from LPS-treated animals showed increased cellular apoptosis, lipid peroxidation, decreased glutathione levels, altered activities of antioxidant enzymes (catalase, glutathione peroxidase, superoxide dismutase) and focal inflammation confined to the parenchyma. A treatment with taurine was found to significantly attenuate all these alterations, with the protection being, in all instances, greater when given before rather than after LPS. The present results suggest that taurine is endowed with antiinflammatory and antioxidant properties that are protective in the lung against the deleterious actions of Gram negative bacterial endotoxin.
\end{abstract}

\section{Background}

Acute lung injury (ALI) is a characteristic sequel to infection by Gram negative bacteria and an important cause of morbidity and mortality in humans [1]. A common causative factor of ALI is lipopolysaccharide (LPS), an endotoxin present in the bacterial outer membrane [2]. Typical manifestations of ALI are alveolar and airway inflammatory response [3,4], the presence of inflammatory cells and proteinaceous fluid in air spaces $[5,6]$, increased microvascular permeability due to endothelial barrier disruption $[7,8]$, bronchoalveolar cell death [9],

\footnotetext{
* Correspondence: claucam@usa.net

† Contributed equally

Department of Pharmaceutical Sciences, St. John's University, College of Pharmacy and Allied Health Professions, 8000 Utopia Parkway, Jamaica, New York 11439, USA

Full list of author information is available at the end of the article
}

and cellular changes suggestive of lung inflammation and/or injury [10]. One major contributory factor to the pathogenesis of ALI is the release of reactive oxygen species (ROS) and reactive nitrogen species (RNS), proteolytic enzymes, lipid mediators and proinflammatory cytokines principally from neutrophils and alveolar and interstitial macrophages [9]. The ensuing overwhelming oxidative and nitrosative stresses [10,11], in turn, cause direct damage to DNA [9], apoptosis [12], deplete reduced glutathione (GSH) stores [13-15], promote lipid peroxidation (LPO) $[16,17]$, protein nitration and protein activity alteration $[18,19]$, inactivate antioxidant and antiproteinase enzymes [9], and activate transcriptional factors mediating the expression of proinflammatory genes in phagocytic cells and in endothelial and epithelial lung cells $[9,20-22]$. 
The relevance of oxidative stress to the development of ALI is supported by the results of studies in experimental animal models of ALI demonstrating that low molecular weight antioxidant compounds possessing a wide range of structural features and biological activities are able to decrease the severity of the inflammatory process by reducing the migration of macrophages, monocytes and neutrophils into the lung [23] and the production of ROS and RNS by these cells [24,25]. One of the compounds that has demonstrated protective actions in the lung against inflammation by LPS and other exogenous agents is taurine (TAU), a nonprotein amino acid with a ubiquitous distribution and a high concentration in human tissues. As an antioxidant, TAU is rather unique since it is able to attenuate LPO and the loss of intracellular antioxidant defenses under conditions of oxidative stress in spite of lacking a readily oxidizable functionality [26] and has the ability to selectively scavenge free radicals generated during ALI $[27,28]$. For example, the addition of this compound to cultured pneumocytes was found to reduce the LPSinduced generation of ROS and the activation of mitogen-activated protein kinases and Bax [29]; and the pretreatment of rats with 5\% TAU in the drinking water resulted in a lower number of inflammatory leukocytes infiltrating the lung and in attenuation of the focal bronchiolar hyperplasia that developed from a short contact with ozone [30]. Moreover, an earlier study from this laboratory determined that a 3-day treatment of hamsters with TAU was able to reduce the number of proinflammatory leukocytes, the expression of tumor necrosis factor receptor 1 (TNFR1) on macrophages, the activation of caspase- 3 activity and accompanying apoptosis, LPO and the decreases in GSH and activities of antioxidant enzymes in bronchoalveolar lavage fluid (BALF) samples as a result of a challenge with LPS [31]. On the basis of these results, the present study was undertaken in hamsters with the specific purpose of determining: (a) the effects of TAU on the inflammation, oxidative stress and apoptosis that develops in lung tissue as a result of an exposure to LPS, (b) the role of the order of administration of TAU relative to that of LPS on the magnitude of the effects demonstrated by TAU, and (c) the extent to which the findings for lung tissue samples correlate with those gathered for markers of inflammation in BALF samples.

\section{Methods}

\section{Materials and chemicals}

All the chemicals, reagents and assay kits used in the study were purchased from commercial sources in the USA. $\mathrm{H}_{2} \mathrm{O}_{2}(30 \% \mathrm{w} / \mathrm{w})$, LPS (serotype: O26:B6 obtained from American Type Culture Collection no. 12795; with short chain-length approximating that of mutant rough strain LPS), PBS, GSH, TAU, TCA, SSA, TEP and TBA were from Sigma-Aldrich, St. Louis, MO; $0.1 \mathrm{~N}$ and $6 \mathrm{~N}$ $\mathrm{HCl}$ were from Mallinckrodt Baker, Inc., Phillipsburg, NJ; and metaphosphoric acid was from Aldrich Chemical Co., Inc., Milwaukee, WI.

\section{Animals}

Female Golden Syrian hamsters (5-6 weeks old, 100 \pm 15 $\mathrm{g}$ in weight, 6 per group) were purchased from Harlan, Indianapolis, IN, USA. The animals were housed in a temperature-controlled room $\left(21 \pm 1^{\circ} \mathrm{C}\right)$ with a $12 \mathrm{hr}$ light-12 hr dark cycle; and had free access to a standard hamster chow and filtered tap water for at least 7 days. The study received the approval of the Institutional Animal Care and Use Committee of St. John's University, and the animals were cared in accordance with the guidelines established by the United States Department of Agriculture.

\section{Treatments with LPS and TAU}

To determine the effects of a pretreatment with taurine on LPS-induced lung injury, hamsters were treated with TAU (as a solution in phosphate buffered saline (PBS) $\mathrm{pH} 7.4,50 \mathrm{mg} / \mathrm{kg} / 0.5 \mathrm{ml} /$ day) by the intraperitoneal (i. p.) route for 3 days, followed successively by an i.p. dose of pentobarbital sodium $(90 \mathrm{mg} / \mathrm{kg} / 0.4 \mathrm{ml})$ to induce anesthesia, and an intratracheal (i.t.) instillation of LPS $(0.2 \mathrm{ml}$ of $0.1 \mathrm{mg} / \mathrm{ml}$ in PBS $\mathrm{pH} 7.4)$ on day 4 . Controls were treated with: (a) i.p. PBS pH 7.4 for 3 days followed by i.t. LPS on day 4 (positive control), and (b) only i.t. PBS pH 7.4 on day 4 (negative control). To determine the effects of a posttreatment with TAU on LPS-induced lung injury, the hamsters received LPS $(0.2$ $\mathrm{ml}$ of $0.1 \mathrm{mg} / \mathrm{ml}$ in PBS $\mathrm{pH} 7.4$ ) by i.t. instillation on day 1 , followed by TAU (as a solution in phosphate buffered saline (PBS) pH 7.4, $50 \mathrm{mg} / \mathrm{kg} / 0.5 \mathrm{ml} /$ day) by i.p. route for 3 days. Control animals were treated with (a) i.t. LPS on day 1 followed by i.p. PBS pH 7.4 on days 2 to 4 (positive control), and (b) only with i.t. PBS pH 7.4 (negative control). All i.t. instillations were carried out using a $1-\mathrm{ml}$ syringe fitted with a 27 -gauge needle. Following an i.t. delivery, the incision was closed with metal clips.

\section{Collection of lung and BALF samples}

On day 5, 24 h after a LPS instillation or a TAU treatment, the animals were sacrificed using a high dose of pentobarbital sodium ( $240 \mathrm{mg} / \mathrm{kg} / 0.7 \mathrm{ml}$, i.p.), and BALF samples were collected by rinsing the bronchoalveolar surface with $\mathrm{PBS} \mathrm{pH} 7.4$, and bringing the volume of the pooled washings to $10 \mathrm{ml}$ with additional PBS pH 7.4. Immediately thereafter, the lungs were surgically removed, washed without delay with ice-cold physiologic saline, patted dry with filter paper, 
frozen in liquid nitrogen, and kept at $-20^{\circ} \mathrm{C}$ until used in an assay.

\section{Preparation of lung homogenates}

Following their removal, the lung samples were rinsed immediately with physiological saline, patted dry with filter paper, weighed, and perfused with ice-cold physiologic saline. A portion of lung sample was mixed with PBS pH 7.4 in a 1:30 (w/v) ratio and made into a fine homogenate with a hand held tissue homogenizer (Tissue-Tearor ${ }^{\bullet}$, BioSpec Products, Inc., Bartlesville, OK) while keeping the mixture cold with the help of an ice bath. After a short sonication, the suspension was centrifuged at $14,000 \mathrm{rpm}$ for $30 \mathrm{~min}$, and the supernatant used for the assays of MDA, GSH, CAT, SOD and GPx.

\section{Assay of MDA}

The concentration of MDA in the lung was measured as TBARS using the method of Buege and Aust [32]. An aliquot of lung homogenate was mixed with a reagent containing $15 \%$ TCA (w/v) $-0.375 \%$ TBA (w/v)- $0.25 \mathrm{~N}$ $\mathrm{HCl}$, and the mixture heated at $90^{\circ} \mathrm{C}$ for $1 \mathrm{hr}$. After allowing the mixture to cool to room temperature, and a brief centrifugation step to remove insolubles, the absorbance of the clear supernatant was read on a spectrophotometer at $535 \mathrm{~nm}$. The concentration of MDA was derived from a standard curve prepared from serial dilutions of a $3.2 \mu \mathrm{M}$ stock solution of TEP that were treated in identical manner as the lung homogenate samples. The concentration of MDA was expressed as $\mathrm{nmol} / \mathrm{mg}$ of protein.

\section{Assay of GSH}

The concentration of GSH in the lung homogenate was measured following its reaction with DTNB according to Ellman [33]. An aliquot of lung homogenate was mixed with $5 \%$ metaphosphoric acid, the mixture centrifuged at $2000 \mathrm{x} \mathrm{g}$ for $5 \mathrm{~min}$, and an aliquot of the clear supernatant was mixed with $1.9 \mathrm{ml}$ of $0.1 \mathrm{M}$ phosphate buffer $\mathrm{pH} 8.0$ and $20 \mu \mathrm{l}$ of $0.02 \mathrm{M}$ DTNB in $0.1 \mathrm{M}$ phosphate buffer $\mathrm{pH} 8.0$, and the absorbance of the resulting product read at $412 \mathrm{~nm}$ on a spectrophotometer. The concentration of GSH in the sample was derived by reference to a calibration curve of GSH prepared from serial dilutions of a $240 \mu \mathrm{M}$ GSH stock solution that were treated in identical manner as the lung homogenate samples. The result was reported as $\mu \mathrm{mol} /$ mg of protein.

\section{Assay of CAT activity}

The activity of CAT was measured spectrophotometrically as described by Aebi [34]. An aliquot of lung homogenate was mixed with 10 times its volume of PBS
$\mathrm{pH} 7.4$ and of $30 \mathrm{mM} \mathrm{H}_{2} \mathrm{O}_{2}$ in a spectrophotometric quartz cuvette, and the absorbance of the reaction mixture read without delay at $240 \mathrm{~nm}$ twice, immediately after mixing and $1 \mathrm{~min}$ later. The activity of CAT, in U/ $\mathrm{min} / \mathrm{mg}$ of protein, was calculated from the equation $\left[\Delta \mathrm{OD} \cdot \mathrm{V}_{\mathrm{c}} \cdot \mathrm{df} / 0.071 \cdot \mathrm{V}_{\mathrm{s}}\right]$, where $\Delta \mathrm{OD}$ is the difference between the first and second absorbance readings; $V_{c}$ is the volume of the spectrophotometric cuvette in $\mathrm{ml} ; \mathrm{V}_{\mathrm{s}}$ is the volume of sample taken in $\mathrm{ml}$; $\mathrm{df}$ is the dilution factor; and 0.071 is the molar extinction coefficient of $\mathrm{H}_{2} \mathrm{O}_{2}$.

\section{Assay of GPx activity}

The activity of GPx was measured indirectly by a coupled reaction with glutathione reductase using the spectrophotometric method of Günzler and Flohé [35]. The reaction mixture contained an aliquot of lung homogenate, glutathione reductase solution $(54 \mathrm{U} / \mathrm{ml})$, $10 \mathrm{mM}$ GSH, and $15 \mathrm{mM} \beta$-NADPH in PBS pH 8.0. After standing at room temperature, the reaction mixture was mixed with $3 \mathrm{mM} \mathrm{H}_{2} \mathrm{O}_{2}$, and the change in absorbance of the reaction mixture at $340 \mathrm{~nm}$ was measured for $1 \mathrm{~min}$. The results are expressed in $\mathrm{U} / \mathrm{min} / \mathrm{mg}$ of lung.

\section{Assay of SOD activity}

This enzyme activity was determined based on the inhibitory action of SOD on the reduction of NBT by superoxide anion generated by a xanthine-xanthine oxidase system and the conditions described by Ukeda et al. [36]. For this purpose, an aliquot of lung homogenate was mixed with $15 \%$ bovine serum albumin in PBS $\mathrm{pH}$ 8.0, $3 \mathrm{mM}$ xanthine, $3 \mathrm{mM}$ EDTA, $0.75 \mathrm{mM} \mathrm{NBT}$, and $56 \mathrm{U} / \mathrm{ml}$ of xanthine oxidase. After allowing the reaction mixture to stand at room temperature for $30 \mathrm{~min}$, its absorbance was read on a spectrophotometer at $560 \mathrm{~nm}$. The enzyme activity was expressed as $\mathrm{U} / \mathrm{min} /$ mg of lung.

\section{Histological studies}

Following euthanasia of the animals with a high dose of pentobarbital $(240 \mathrm{mg} / \mathrm{kg} / 0.7 \mathrm{ml}$, i.p.), the lungs were fixed in situ with $10 \%$ neutral-buffered formalin for about $2 \mathrm{hr}$ at a pressure of $20 \mathrm{~mm}$ of water. The lungs, along with the attached heart, were surgically removed through a vertical incision along the thorax, and fixed in $10 \%$ neutral-buffered formalin for an additional $48 \mathrm{hr}$. After excising any extrapulmonary structures with the help of a scalpel, the lungs were cut into pieces of a size suitable for histological processing, put though a standard embedding procedure in paraffin, sectioned on a microtome, and stained with $\mathrm{H} \& \mathrm{E}$. The sections where then examined for evidence of inflammation with the help of a light microscope. 


\section{Determination of lung injury}

The presence of lung injury in the tissue sections was graded using the scale described by Szarka et al. [37]. The following scoring values were used: $0=$ no reaction in the alveolar walls, $1=$ diffuse reaction in the alveolar walls but without thickening of the interstitium, $2=$ diffuse presence of inflammatory cells in the alveolar walls with a slight thickening of the interstitium, $3=$ moderate interstitial thickening accompanied by inflammatory cell infiltrates, and $4=$ interstitial thickening involving more than one-half of the microscopic field. Results were expressed as the average of the values from 50 microscopic fields.

\section{Immunocytochemistry of TNFR1}

Cytocentrifuged lung preparations were fixed with ethanol and permeated with an alcohol-acetic acid (2:1) mixture. Endogenous peroxidase activity was quenched with $0.3 \% \mathrm{H}_{2} \mathrm{O}_{2}$ and nonspecific binding was blocked with goat serum (Vector Laboratories, Inc., Burlingame, CA). After an incubation with anti-mouse TNFR1 polyclonal antibody (Stressgen, Victoria, BC, Canada) at room temperature for $30 \mathrm{~min}$, and a rinsing with $\mathrm{PBS} \mathrm{pH}$ 7.4, the sample was successively incubated with biotinylated goat anti-rabbit antibody or rabbit anti-rat antibody (Stressgen, Victoria, BC, Canada) at room temperature for 1 $\mathrm{hr}$, and with $\mathrm{ABC}$ reagent (Vector Laboratories, Inc., Burlingame, VT) for $1 \mathrm{hr}$, prior to staining with 3,3'-diaminobenzidine substrate in the dark, and counterstaining with methyl green. The slides were examined under a light microscope at 400x magnification for the presence of macrophages stained in brown. For comparative purposes, a negative control sample that had not been incubated with TNFR1 primary antiserum was also examined. The results were expressed as the number of macrophages staining for TNFR1 in a group of 200 cells counted in the same section. The number of macrophages staining for TNFR1 was reported as a percentage of the total number of macrophages examined.

\section{TUNEL staining for apoptosis}

Lung tissue sections were digested with $20 \mu \mathrm{g} / \mathrm{ml}$ of proteinase K (Sigma-Aldrich, St. Louis, MO) at room temperature, washed with distilled water, and treated with $0.3 \% \mathrm{H}_{2} \mathrm{O}_{2}$ in PBS pH 7.4 to quench endogenous peroxidase. After incubation with TdT enzyme (Chemicon International, Temecula, CA) at $37^{\circ} \mathrm{C}$ for $1 \mathrm{hr}$, the samples were exposed to anti-digoxigenin conjugate (Chemicon International, Temecula, CA) at room temperature for $30 \mathrm{~min}$. The samples were stained with DAB peroxidase substrate (Vector Laboratories, Inc., Burlingame, VT), counterstained with methyl green, and examined under a microscope. Twenty-five high-power (HPF, 400x magnification) microscopic fields were examined, and the results were expressed as the mean number of TUNEL-positive cells per HPF.

\section{Statistical analysis}

The experimental results are expressed as mean \pm standard error of the mean (S.E.M.) for $n=6$. A significant difference between control and treatment groups was determined by Student's t-test followed by one-way analysis of variance (ANOVA) and Newman-Keuls multiple-range test. A $P$ value $\leq 0.05$ was taken as an indication of a statistically significant difference.

\section{Results}

Effects of LPS and TAU-LPS on indices of lung oxidative stress

Evidence of the occurrence of oxidative stress in the lung as a result of an acute exposure to LPS was inferred from the levels of MDA (as TBARS) and GSH and from the activities of the antioxidant enzymes CAT, GPx and SOD in lung homogenates. As shown in Figure 1, LPS stimulated LPO in lung tissue since it markedly and significantly increased the formation of MDA (by $>100 \%, \mathrm{P}<0.001$ vs. control). The administration of TAU for 3 days, either before or after LPS, resulted, in both instances, in a significant reduction (by $46 \%, \mathrm{P}<0.01$ and $31 \%, \mathrm{P}<0.05$, respectively) in MDA formation induced by LPS.

The results presented in Figure 2 indicate that, in comparison to control values, LPS was able to reduce the lung GSH to a significant extent (by $\geq 20 \%, \mathrm{P}<0.05$ ). However, in the presence of TAU, diverging results were obtained depending on the timing of TAU administration. While a pretreatment with this amino acid virtually abolished the effect of LPS on lung GSH (only 6\%

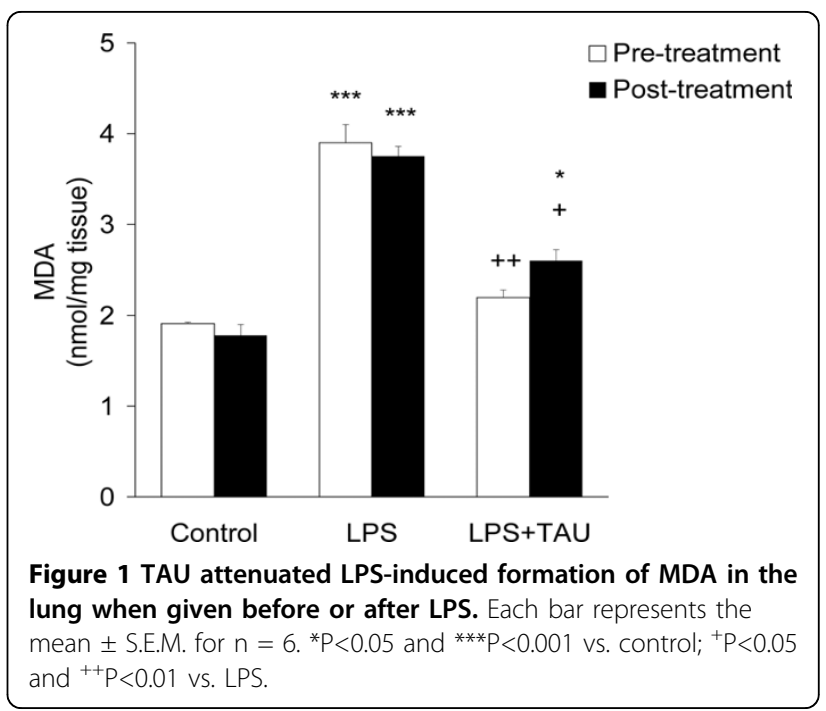




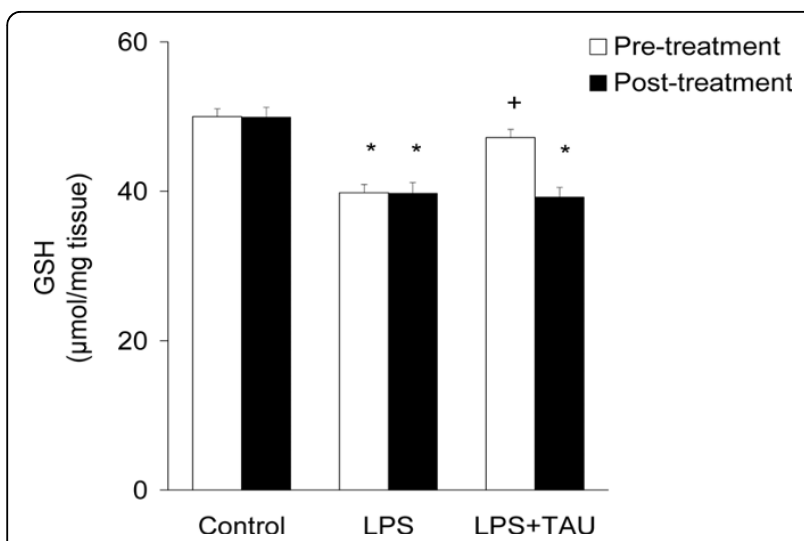

Figure 2 TAU prevented the LPS-induced depletion of lung GSH when given before, but not after, LPS. Each bar represents the mean \pm S.E.M. for $n=6{ }^{+} P<0.05$ vs. control; ${ }^{+} P<0.05$ vs. LPS.

decrease), a post-treatment was without an obvious effect.

From the results summarized in Figures 3,4,5, it is evident that LPS exerted contrasting effects on the activities of the major antioxidant enzymes. On the one hand, it lowered the mean activity values of both CAT (by $\sim 15 \%, \mathrm{P}<0.05$ ) (Figure 3 ) and SOD (by 27\%, $\mathrm{P}<0.05$ ) (Figure 4) and elevated that of GPX (by $\sim 98 \%, \mathrm{P}<0.001$ ) (Figure 4) in comparison to the respective control values. Regardless of its order of administration relative to that of LPS, TAU was able to counteract these alterations throughout. Thus, in the case of CAT the activities were $75 \%$ and $\sim 46 \%$ greater than control when given along with LPS as a pretreatment and posttreatment, respectively (both at $\mathrm{P}<0.001$ vs. LPS). Likewise, TAU lowered the increase in SOD activity induced by LPS by

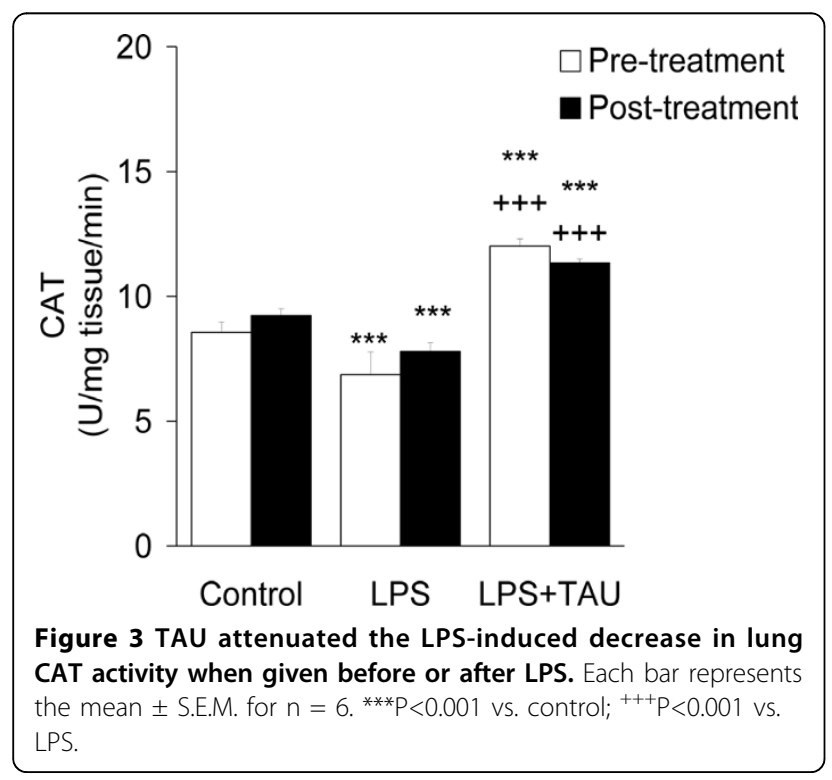

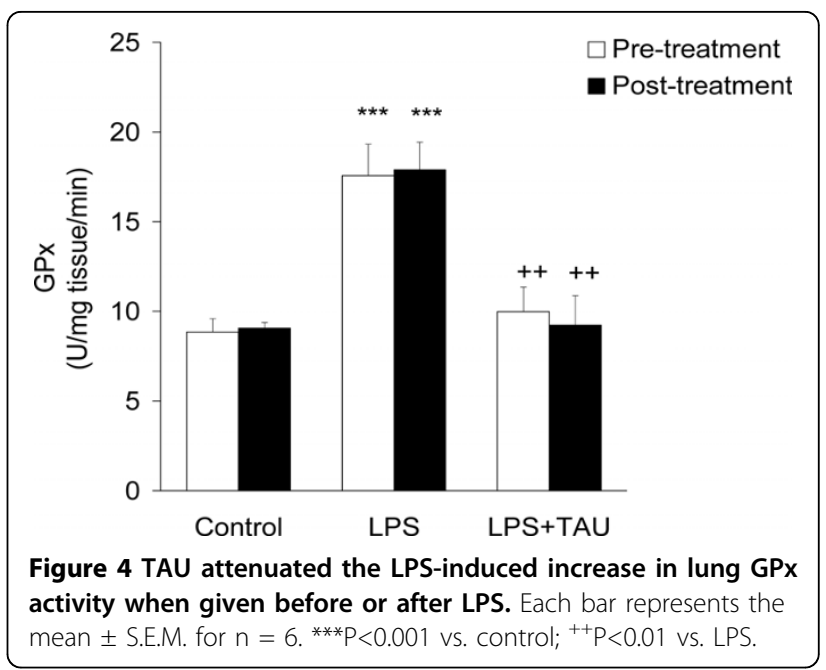

about the same extent when given before (31\% reduction) or after (34\% reduction) LPS (both at $\mathrm{P}<0.01$ vs. LPS). In contrast, while TAU attenuated the elevation in GPx activity caused by LPS, it was somewhat more effective when given as a posttreatment (by $~ 49 \%$ ) than as a pretreatment (by $43 \%$ ) to LPS (both at $\mathrm{P}<0.01$ vs. LPS) (Figure 5).

Effects of LPS and TAU-LPS on total leukocyte, neutrophil and total neutrophil counts in BALF

As shown in Figure 6, an acute exposure to LPS led to a profound increase in the total number of leukocytes infiltrating the lung (by 12.5 -fold, $\mathrm{P}<0.001$ ) relative to the number observed in control samples. From the results presented in Figure 7, it is apparent that the administration of TAU, either before or after LPS, led to a small reduction in the number of neutrophils that entered the lung as a result of an exposure to LPS (by

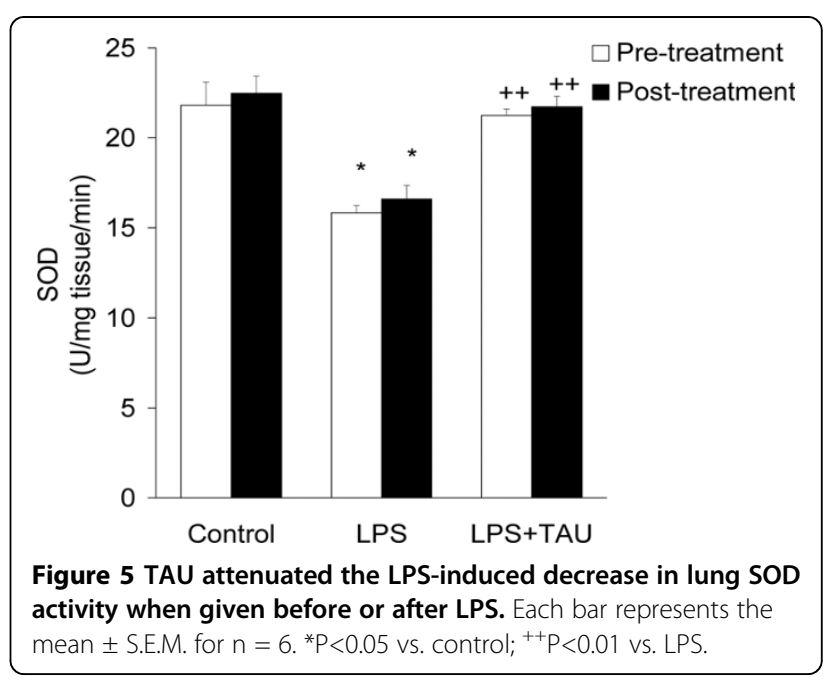




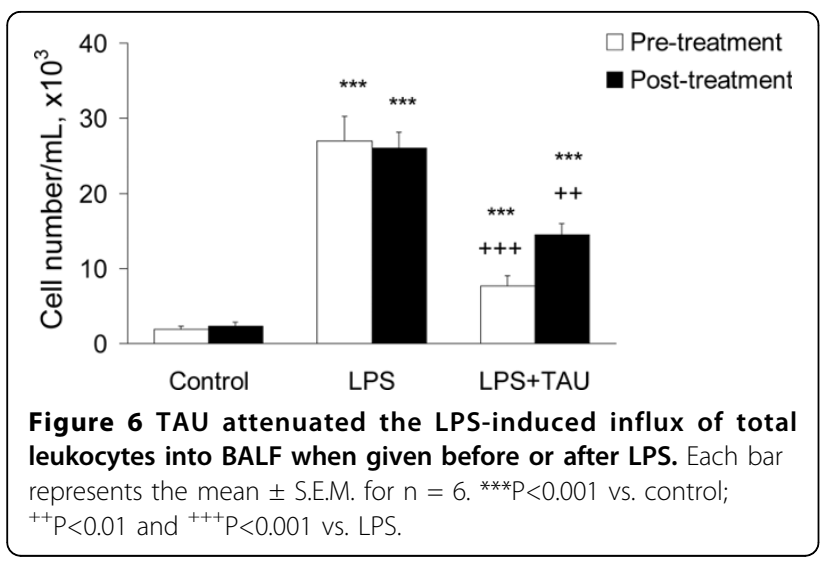

$15 \%, \mathrm{P}<0.05$, and $11 \%$, respectively). Moreover, as shown in Figures 8 and 9, it is evident that a treatment with TAU resulted in a significant attenuation of the enhancing action of LPS on the total number of lung neutrophils, with a pretreatment providing a greater effect (85\% decrease at $\mathrm{P}<0.001$ vs. LPS) than a post-treatment (53\% decrease at $\mathrm{P}<0.01$ vs. LPS).

\section{Effects of LPS and TAU-LPS on the expression of TNFR1 on BALF macrophages}

An acute exposure to LPS led to a marked increase in the expression of TNFR1 by BALF macrophages (by $\sim 47$-fold, $\mathrm{P}<0.001$ vs. control). This change was significantly attenuated by a 3-day treatment with TAU, with the attenuation being greater when TAU was given ahead rather than after LPS (reductions equal to $59 \%$ and $39 \%$ respectively, $\mathrm{P}<0.01$ for both vs. LPS alone) (Figures 10 and 11).

\section{Effects of LPS and TAU-LPS on apoptosis of lung cells} A 3-day treatment with TAU, either before or after one with LPS, resulted in a significant decrease in the

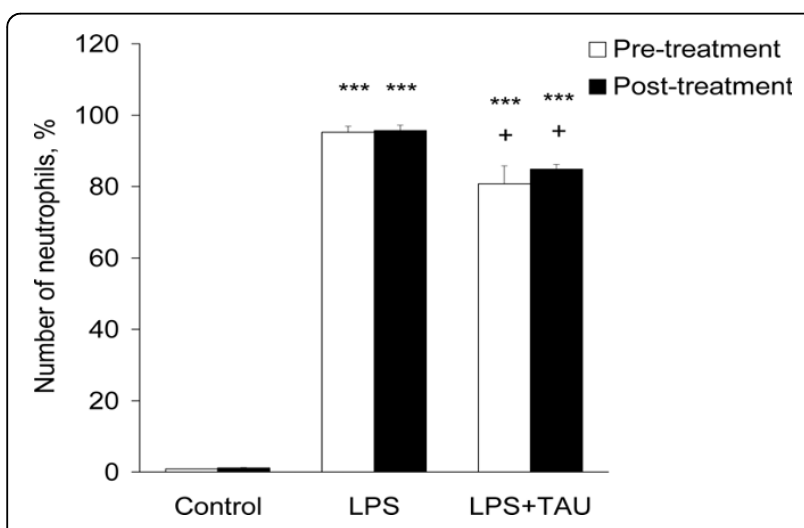

Figure 7 TAU attenuated the LPS-induced influx of neutrophils into BALF when given before or after LPS. Each bar represents the mean \pm S.E.M. for $n=6 .{ }^{* * *} P<0.001$ vs. control; ${ }^{+} P<0.05$ vs. LPS.

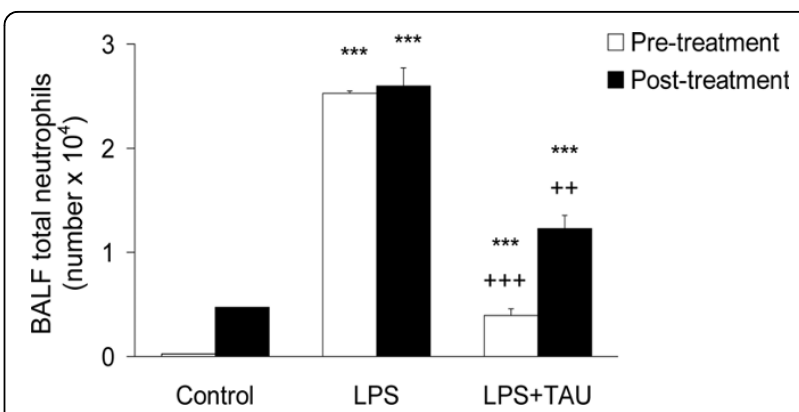

Figure 8 TAU attenuated the LPS-induced influx of total neutrophils into BALF when given before or after LPS. Each bar represents the mean \pm S.E.M. for $n=6 .{ }^{* *} P<0.001$ vs. control; ${ }^{++} \mathrm{P}<0.01$ and ${ }^{+++} \mathrm{P}<0.001$ vs. LPS.

number of alveolar cells that had entered apoptosis as a result of an exposure to LPS (Figures 12 and 13). Based on the results of a TUNEL assay, it was determined that a pretreatment with TAU was more effective in curtailing apoptosis $(0.4$ labeled cells per $\mathrm{HPF}, \mathrm{P}<0.001)$ than a posttreatment $(0.5$ labeled cells per $\mathrm{HPF}, \mathrm{P}<0.01)$ when compared to the number of apoptotic cells seen with LPS alone (0.8 labeled cells per HPF, $\mathrm{P}<0.001$ vs. control). Because of the limitations imposed by the procedure used to stain the alveolar cells, only those cells occupying the septa were counted.

\section{Effects of LPS and TAU-LPS on the inflammatory index and on lung histology}

The inflammatory index was used to quantitatively assess the extent of lung inflammation as a result of an acute exposure to LPS. The results presented in Figure 14 suggest that the increase in the value of this parameter by LPS could be significantly attenuated by a preor post-treatment with TAU (from 3.0 to $1.8, \mathrm{P}<0.001$ or from 3.0 to $2.4, \mathrm{P}<0.01$. respectively). The mean inflammatory index of animals receiving only PBS (0.2) probably reflects a transient inflammatory response caused by the intratracheal instillation procedure itself. Furthermore, TAU was found to prevent the inflammatory response to LPS from spreading beyond the parenchymal tissue and into the airways (Figure 15).

\section{Discussion}

Inflammation and oxidative stress are two closely related events that contribute to ALI as a result of an exposure to LPS. The inflammatory response that follows the instillation of LPS into the lungs appears to develop through an early and late phase process [38]. In the early phase, there is an increase in BALF neutrophils, albumin, free radical generation by the pulmonary endothelium and neutrophils, upregulation of adhesion molecules, and the release of cytokines and chemokines for the massive recruitment of macrophages and 


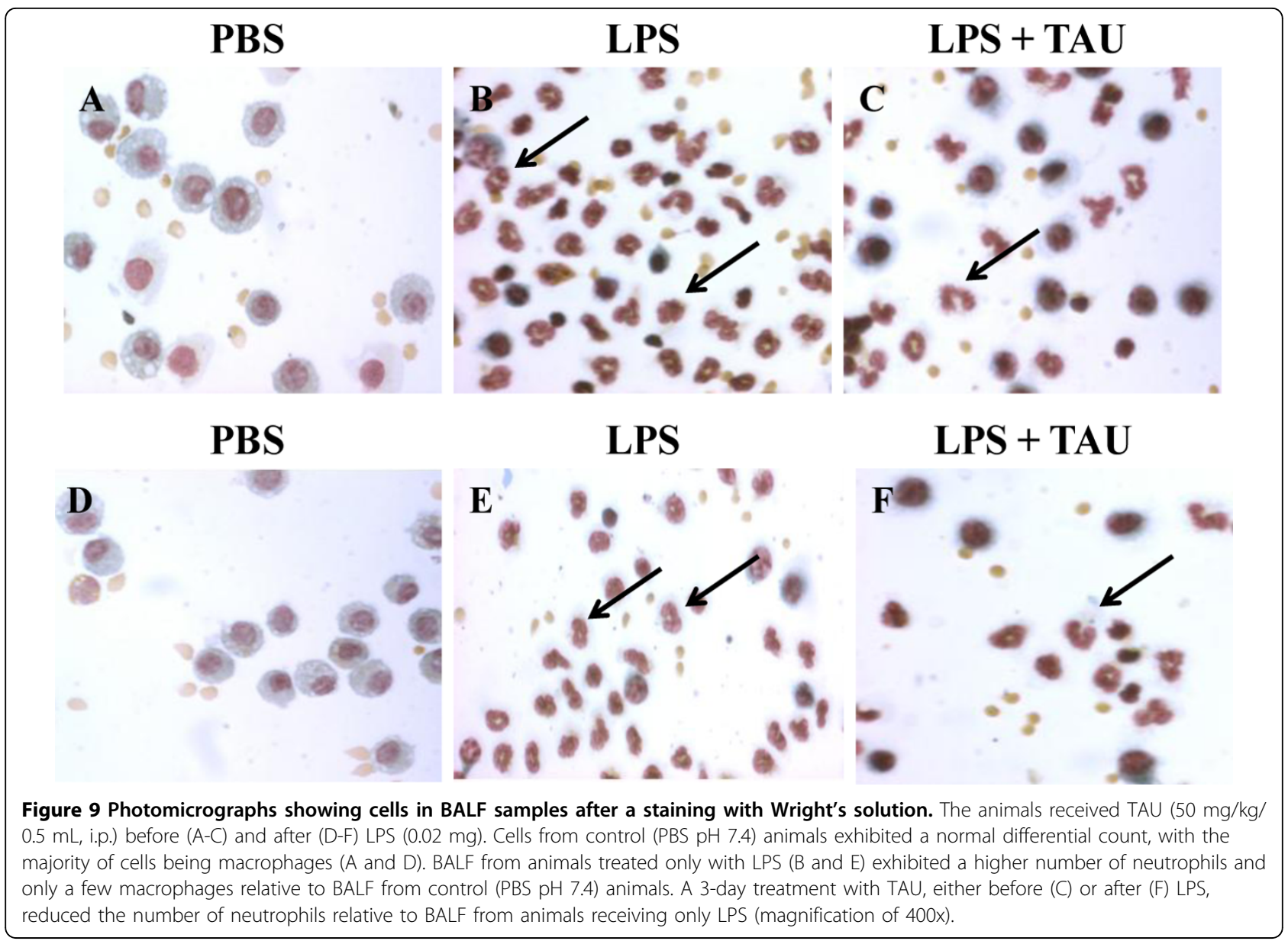

neutrophils within the pulmonary capillaries and of neutrophils in the air spaces of the lungs [14,39]. The late phase, taking place 24-48 $\mathrm{hr}$ after LPS instillation, is characterized by normalization of cytokine levels and increases in the number of BALF neutrophils, monocytes, macrophages and lymphocytes [38]. In the lung

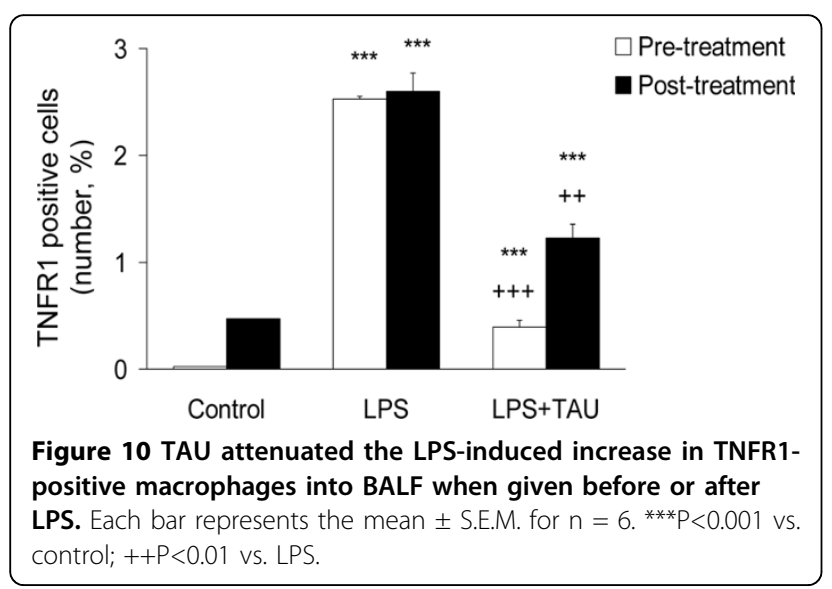

epithelium, TNFR1 seems to facilitate the recruitment of neutrophils after an exposure to LPS, in part by enhancing chemokine secretion [39] and to participate in a caspase-mediated signaling mechanism leading to apoptotic cell death $[40,41]$. On the other hand, the activation of monocytes, macrophages and other cells is the result of an interaction between LPS, bound to a LPSbinding protein (LBP) in the circulation, and CD14/ TLR4 receptor complex on the target cells and culminates in the activation of transcription factors for cytokine production and ROS generation $[38,42]$. The upregulated release of ROS by phagocytic cells, along with proinflammatory cytokines, proteolytic enzymes and prostaglandins, eventually overwhelms the protective intracellular antioxidant mechanisms present in lung tissue and induces a state of oxidative stress characterized by the peroxidative degradation of membrane phospholipids $[9,11]$, the inactivation of antioxidant enzymes $[11,43]$, and the depletion of thiol-bearing molecules such as proteins [44] and GSH [13,43]. Together, these alterations will contribute to lung tissue injury manifested by epithelial permeability changes, 


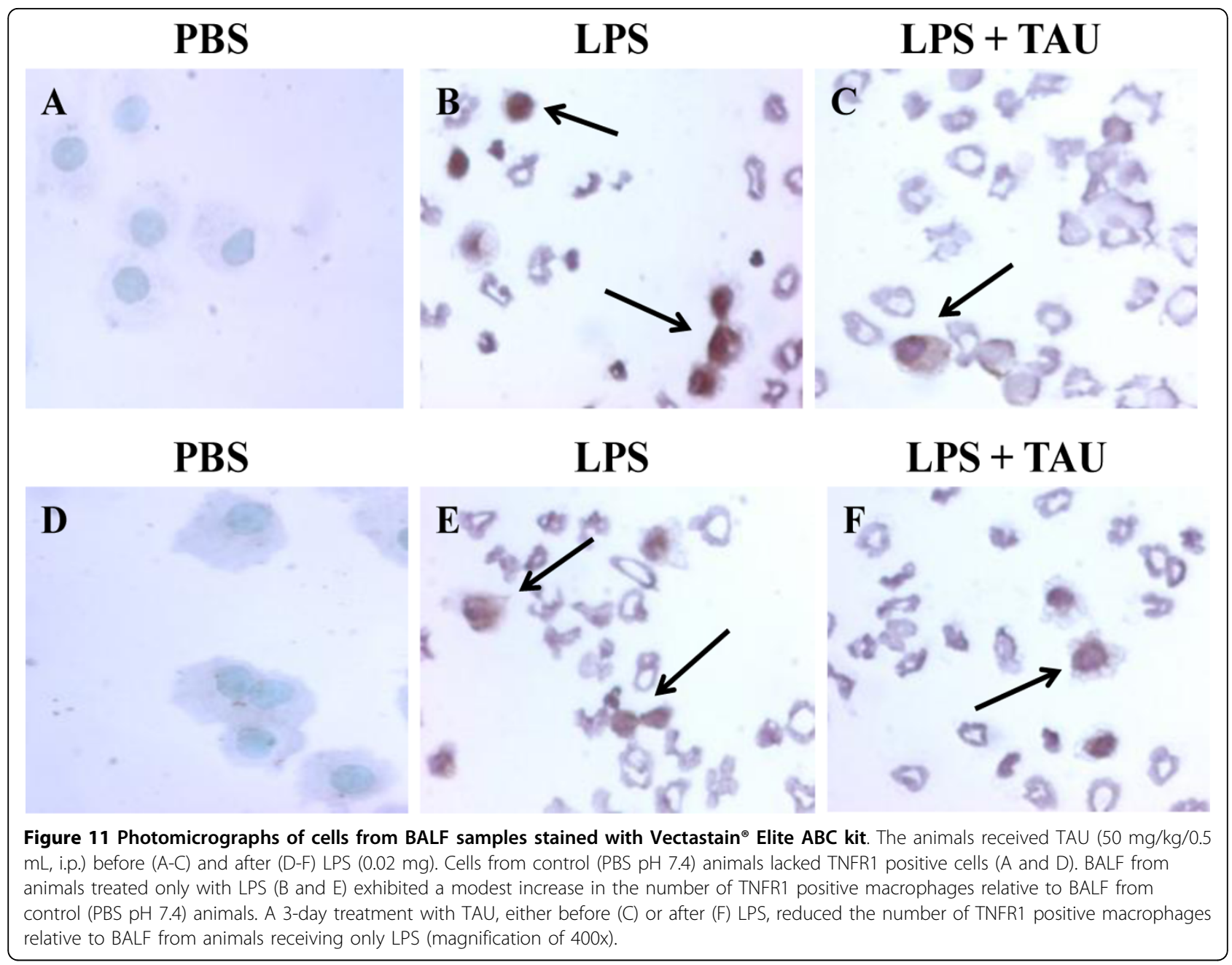

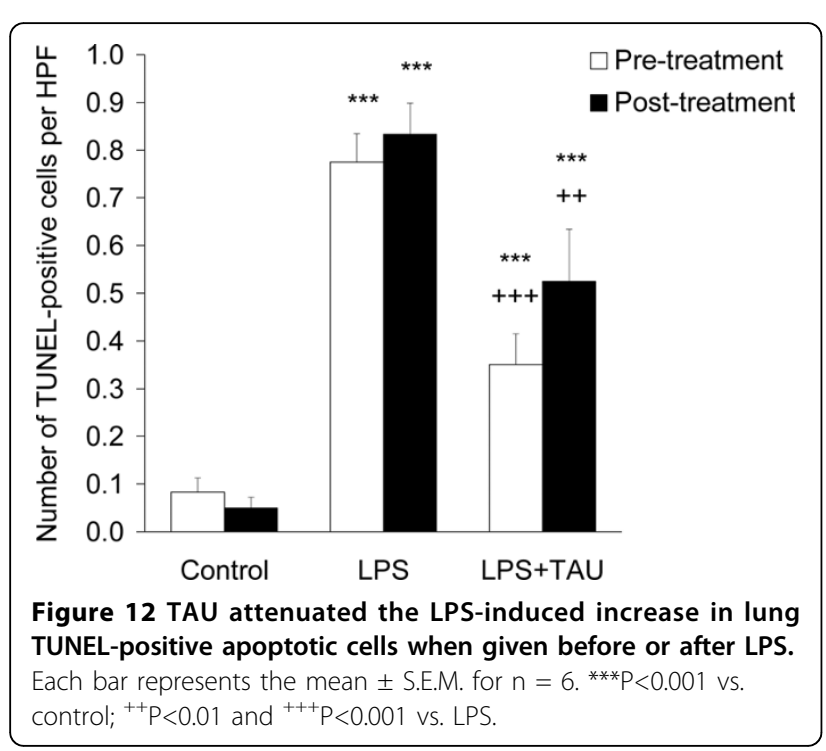

disruption of the alveolar/epithelial barrier, and the development of interstitial edema $[9,39,45]$.

In the present investigation, the intratracheal instillation of LPS into the lungs of Golden Syrian hamsters was sufficient to induce an oxidative stress manifested by increased formation of MDA, decreased GSH, and altered activities of CAT, GPx and SOD. The reduction in GSH, the major nonprotein sulfhydryl compound in the lung, may have been caused by direct oxidation by ROS, by its increased conversion to the oxidized (disulfide) form during the removal of hydrogen peroxide and hydroperoxides by GPx, or because of the inhibitory action of oxidants and proinflammatory mediators on $\gamma$-glutamylcysteine synthetase $(\gamma-$ GCS $)$, the key enzyme for GSH synthesis [14]. These alterations are in agreement with those reported earlier by this and other laboratories for the prooxidant action of LPS on the brain [46], heart [47], and lung $[13,24,48]$, and support the use of antioxidants as adjuncts 


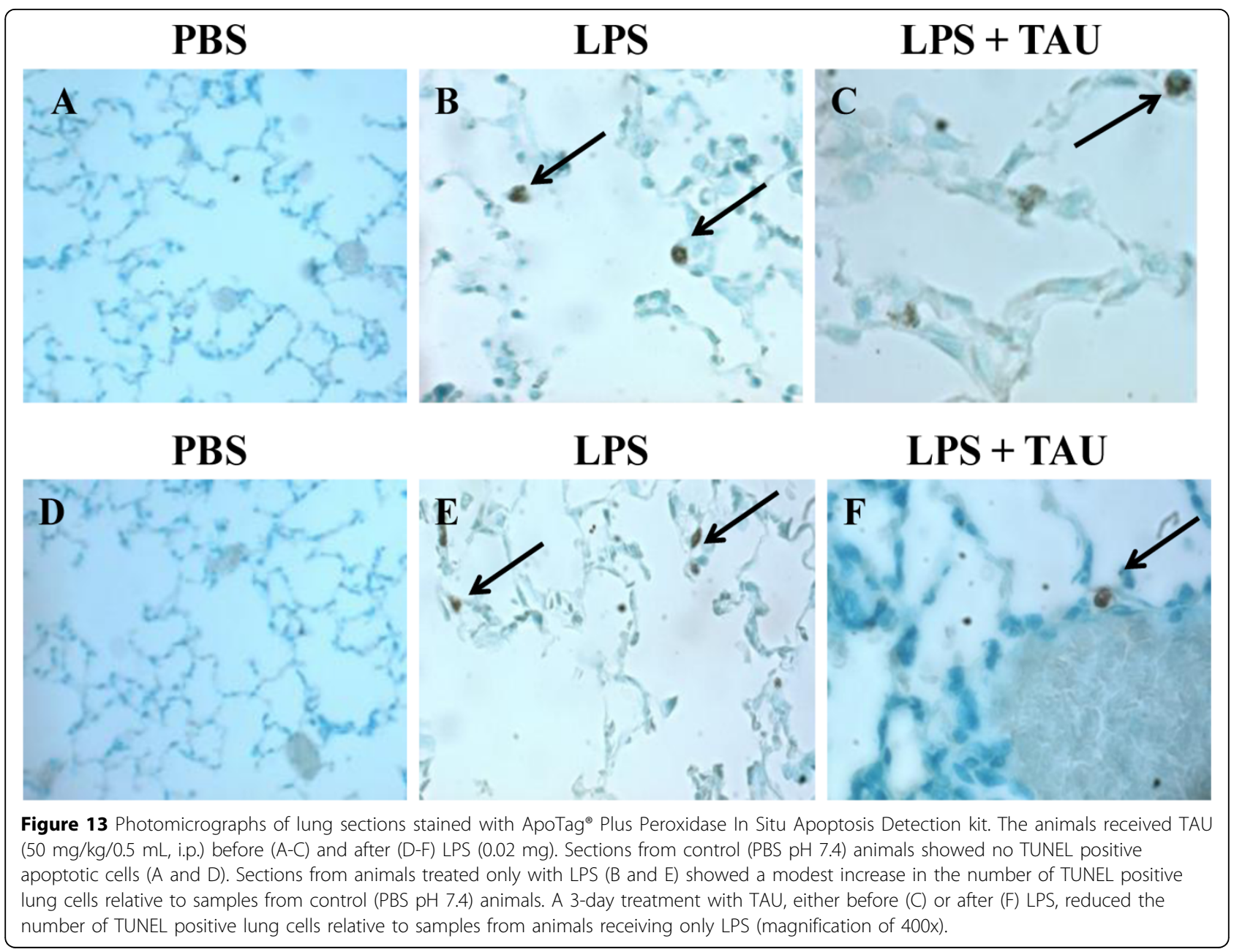

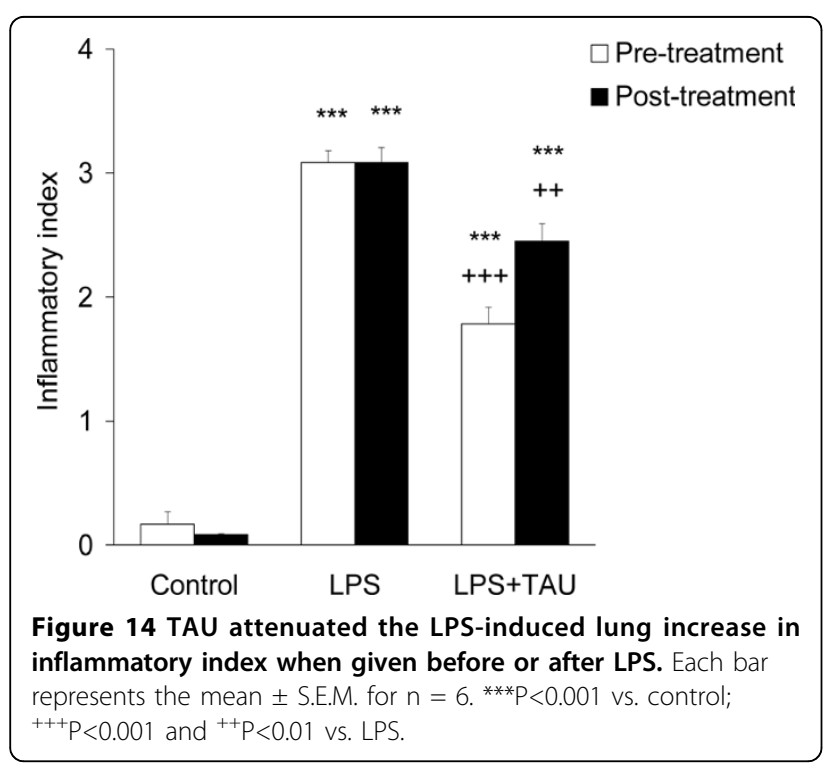

to the management of sepsis by Gram negative bacteria with conventional therapeutic agents.

Since a pretreatment with TAU reduced the formation of MDA significantly and returned the GSH levels to nearly control values confirm earlier results indicating that this amino acid can attenuate LPO and preserve the stores of GSH during periods of oxidative stress, including chronic ethanol consumption [49], diabetes mellitus [50,51], chemically-induced colitis [52] and iron overload [53]. Since the protective effects of TAU were greater when given as pretreatment than as a post-treatment to LPS, it is possible that TAU could be negatively influencing the formation of ROS by phagocytes and surrounding lung cells $[43,52]$. Alternatively, TAU could be preserving the intracellular GSH content by reducing the deleterious effect of oxidants and proinflammatory agents on redox-sensitive transcription factors regulating the gene expression of $\gamma$-GCS in the lungs [14]. 


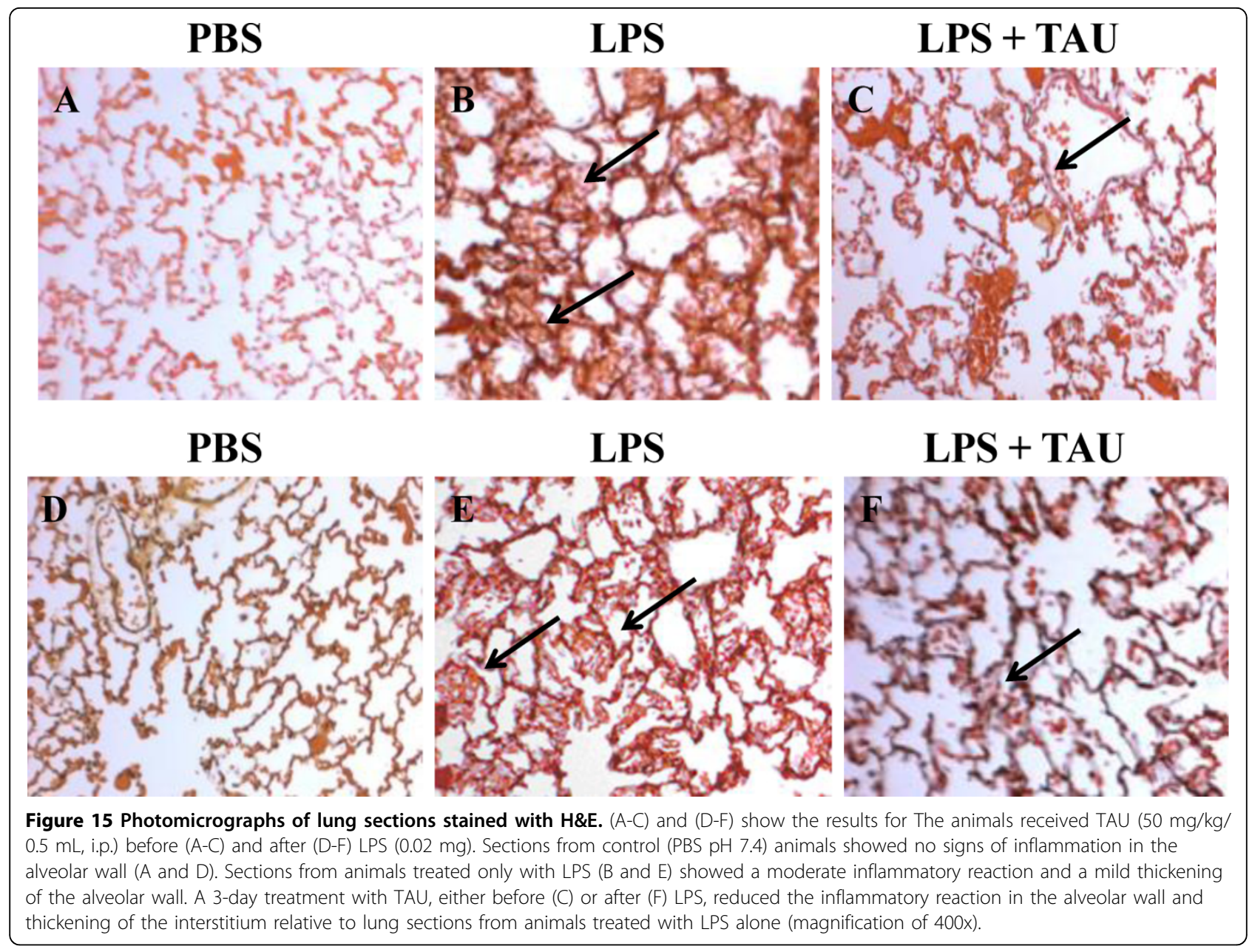

CAT, GPx and SOD are the most important enzymatic defenses available to the lung for the maintenance of a normal antioxidant-oxidant balance. As previously observed with BALF samples from the lung of hamsters exposed to LPS, the activities of both CAT and SOD were reduced and that of GPx increased [13]. Although the same trend of results has been described earlier for the liver of rodents acutely treated with LPS [16,54], considerable variability seems to exist among laboratories regarding the effect of this endotoxin on the lung activities of antioxidant enzymes. For example, it has been reported that LPS reduced the activity of CAT, GPx and SOD in the lung of mice inhaling a solution of LPS in physiological saline for 5 days within an inhalation chamber [11]; had no effect on the GPx activity [55], and increased the CAT activity while decreasing that of SOD activity [25] in the lung. Some of the factors underlining these discrepancies among antioxidant enzyme activities during an inflammatory response to LPS preceding ALI could be the animal species used in the experiments $[56,57]$ and factors related to the endotoxin itself such as the route of administration [56], the dose administered [56], the duration of the exposure [11], and the concentration of the solution used [56].

The higher than normal number of total leukocytes and neutrophils found here for BALF samples from hamsters instilled with LPS confirms the role of endotoxemia as a stimulus for the migration of neutrophils into the lung in response to the in vivo production of chemotatic factor by activated alveolar neutrophils and macrophages [58]. The inhibitory action of TAU on LPS-induced infiltration of the lung by leukocytes in general and by neutrophils in particular appears to occur subsequent to its conversion to TAU chloramine (TAU-Cl) in activated neutrophils upon interaction with hypochlorous acid $(\mathrm{HClO})$ generated in the presence of the myeloperoxidase (MPO)-halide system during the phagocytosis of bacteria [30,59]. While TAU-Cl has been reported to downregulate the production of inflammatory mediators such as $\mathrm{NO}$, prostaglandin $\mathrm{E}_{2}$ and tumor necrosis factor $\alpha$ - (TNF- $\alpha$ ) in activated macrophages and neutrophils in an autocrine manner [60], and to suppress superoxide anion and IL-6 and IL8 production in activated neutrophils $[61,62]$, TAU itself 
was unable to suppress proinflammatory cytokine production [63]. Similarly, although TAU and TAU-Cl can both reduce the formation of products of the respiratory burst by interferon- $\gamma$ (IFN- $\gamma$ )-stimulated peritoneal neutrophils, the effect of TAU-Cl is achieved at a much lower dose that that required for TAU [61]. A similar difference in effects between TAU and TAU-Cl has been verified in vitro for eosinophils [64]. In addition to its effect on the influx of both leukocytes and neutrophils into the lung airspaces, TAU was also found here to attenuate the expression of TNFR1 on macrophages present in BALF as a result of an exposure to LPS, again to a greater extent when given before than after LPS. These findings lend support the long held view that TAU can serve as a potent inhibitor of inflammation and immune response in the lung $[65,66]$, possibly by modulating the transcriptionally regulated production of proinflammatory and chemoattracting cytokines by alveolar macrophages [59,62] and other activated leukocytes $[67,68]$ for the recruitment of blood monocytes and neutrophils into the lung. In this context, TAU-Cl appears to influence cytokine release by acting as a negative effector on the signal pathway for the nuclear translocation and activation of NF- $\kappa$ B for cytokine synthesis by neutrophils, most likely by oxidizing Met 45 residue of $\mathrm{I} \kappa \mathrm{B} \alpha$ [69]. An additional consequence of such a modulatory effect by TAU-Cl, and of relevance to the proinflammatory action of LPS in the lung, is the decreased production of MCP-1 and MCP-2, two chemokines that participate in the recruitment of macrophages by activated neutrophils [59]. In addition, TAU-Cl may be protecting the lungs by preventing the transendothelial migration of neutrophils by shortening their rolling velocity [70]; and by reducing lung arterial pressure, hypoxia, MPO activity, and the excessive release of inflammatory mediators and of products of the respiratory burst activity by neutrophils [30].

As one of the major factors for ALI, LPS is found to induce disseminated endothelial apoptosis prior to endothelial tissue damage and that caspases play an important role in the process [12]. While the protective actions of TAU as TAU-Cl in the lung contrast sharply with the known proapoptotic action associated with this chlorinated TAU derivative on certain cells as a result of direct damage to the mitochondrion [71], in the present study TAU was found to reduce lung cell apoptosis. Such a protection might have resulted from a decrease in TNFR1 expression on lung cells, needed for stimulation of the TNF-induced signaling pathway of apoptosis, and from inhibition of a key caspase downstream in the pathway, which was previously shown by this laboratory to include caspase-3 [31].

\section{Conclusions}

The data reported here strongly suggest that TAU can act in the lung as a protectant against the proinflammatory, prooxidant and apoptotic actions of bacterial endotoxin, and that such a protection is achievable regardless of whether TAU is administered before or after the endotoxin. The magnitude of the protective actions of TAU in the lung against endotoxin can be readily assessed by monitoring the changes in BALF cell counts, TNFR1 expression, the occurrence of alveolar apoptosis, and in indices of oxidative stress; and. are in close agreement with the results gathered by histopathological examination of lung tissue samples.

\section{Abbreviations}

$\mathrm{H}_{2} \mathrm{O}_{2}$ : hydrogen peroxide; LPS: lipopolysaccharide; PBS: phosphate buffered saline; GSH: reduced glutathione; TBARS: thiobarbituric acid reactive substances; TCA: trichloroacetic acid; SSA: sulfosalicylic acid; TEP: 1,1,3,3tetraethoxypropane; TBA: thiobarbituric acid; HCl: hydrochloric acid; BALF: bronchoalveolar lavage fluid; MDA: malondialdehyde; CAT: catalase; SOD: superoxide dismutase; GPx: glutathione peroxidase; DTNB: 5,5'-dithiobis(2nitrobenzoic acid); NBT: nitroblue tetrazolium; EDTA:

ethylenediaminetetraacetic acid; H: hematoxylin; E: eosin.

\section{Acknowledgements}

The authors would like to thank Forest Research Institute, a subsidiary of Forest Laboratories, Inc., Jersey City, New Jersey, for providing financial support to this study.

This article has been published as part as part of Journal of Biomedical Science Volume 17 Supplement 1, 2010: Proceedings of the 17th International Meeting of Taurine. The full contents of the supplement are available online at http://www.jbiomedsci.com/supplements/17/S1.

\section{Authors' contributions}

TMB carried out all experimental work on live animals, performed the cytological and histopathological evaluations. In addition, prepared the figures, performed the statistical analyses, helped with the collection of bibliographical information, and made editorial comments to the article. SNP performed all the biochemical assays on the lung samples, and helped with the preparation of the figures. CAL conceived the project and guided its development, assembled, organized and interpreted the experimental data, and reviewed the pertinent scientific literature.

\section{Competing interests}

The authors declare that they have no competing interests.

Published: 24 August 2010

\section{References}

1. Mei SH, McCarter SD, Deng Y, Parker CH, Liles CW, Stewart DJ: Prevention of LPS-induced acute lung injury in mice by mesenchymal stem cells overexpressing angiopoietin 1. PLoS Med 2007, 4:e269.

2. Caroff M, Karibian D: Structure of bacterial lipopolysaccharides. Carbohyd Res 2003, 338:2431-2447.

3. Leiva M, Ruiz-Bravo A, Jimenez-Valera M: Effects of Telithromycin in in vitro and in vivo models of lipopolysaccharide-induced airway inflammation. Chest 2008, 134:20-29.

4. Tschernig T, Janardhan KS, Pabst R, Singh B: Lipopolysaccharide-induced inflammation in the perivascular space in lungs. J Occup Med Toxicol 2008, 3:17.

5. Chignard M, Balloy V: Neutrophil recruitment and increased permeability during acute lung injury induced by lipopolysaccharide. Am J Physiol Lung Cell Mol Physiol 2000, 279:L1083-L1090. 
6. Li XC, Miyasaka M, Issekutz T: Blood monocyte migration to acute lung inflammation involves both CD11/CD18 and very late activation antigen4-dependent and independent pathways. J Immunol 1998, 161:6258-6264.

7. Reutershan J, Morris MA, Burcin TL, Smith DF, Chang D, Saprito MS, Ley K: Critical role of endothelial CXCR2 in LPS-induced neutrophil migration into the lung. J Clin Invest 2006, 116:695-702.

8. Yi ES, Ulich TR: Endotoxin, interleukin-1, and tumor necrosis factor cause neutrophil-dependent microvascular leakage in postcapillary venules. Am J Pathol 1992, 140:659-663.

9. Chow C-W, Herrera MT, Suzuki T, Downey GP: Oxidative stress and acute lung injury. Am J Respir Cell Mol Biol 2003, 29:427-431.

10. Itoh T, Obata H, Murkami S, Hamada K, Kimura H, Nagaya N: Adrenomedullin ameliorates lipopolysaccharide-induced acute lung injury in rats. Am J Physiol Lung Cell Mol Physiol 2007, 293:L446-L452.

11. Santos Valenca S, Silva Bezerra F, Aguiar Lopes A, Romana-Souza B, Marinho Cavalcante MC, Brando Lima A, Gonçalves Koatz VL, Cristóvão Porto L: Oxidative stress in mouse plasma and lungs induced by cigarette smoke and lipopolysaccharide. Environ Res 2008, 108:199-204.

12. Kawasaki M, Kuwano K, Hagimoto N, Matsuba T, Kunitake R, Tanaka T, Maeyama T, Hara N: Protection from lethal apoptosis in lipopolysaccharide-induced acute lung injury in mice by a caspase inhibitor. Am J Pathol 2000, 157:597-603.

13. Pacht ER, Timerman AP, Lykens MG, Merola AJ: Deficiency of alveolar fluid glutathione in patients with sepsis and the adult respiratory distress syndrome. Chest 1991, 100:1397-1403.

14. Rahman I, MacNee W: Oxidative stress and regulation of glutathione in lung inflammation. Eur Respir J 2000, 16:534-554.

15. Sprong CR, Winkelhuyzen-Janssen AML, Aarsman CJM, van Oirschot JFLM, van der Bruggen $\mathrm{T}$, van Asbeck BS: Low-dose $\mathrm{N}$-acetylcysteine protects rats against endotoxin-mediated oxidative stress, but high-dose increases mortality. Am J Respir Crit Care Med 1998, 157:1283-1293.

16. Hsu D-Z, Chiang P-J, Chien S-P, Huang B-M, Liu M-Y: Parenteral sesame oil attenuates oxidative stress after endotoxin intoxication in rats. Toxicology 2004, 196:147-153.

17. Liu Y-C, Chang AYW, Tsai Y-C, Chan JYH: Differential protection against oxidant stress and nitric oxide overproduction in cardiovascular and pulmonary systems by propofol during endotoxemia. J Biomed Sci 2009, $16: 8$.

18. Bian K, Murad F: Diversity of endotoxin-induced nitrotyrosine formation in macrophage-endothelium-rich organs. Free Radic Biol Med 2001, 31:421-429.

19. Sharma S, Smith A, Kumar S, Aggarwal S, Rehmani I, Snead C, Harmon C, Fineman J, Fulton D, Catravas J: Mechanisms of nitric oxide synthase uncoupling in endotoxin-induced acute lung injury: role of asymmetric dimethylarginine. Vascul Pharmacol 2010, 52:182-190.

20. Blackwell TS, Blackwell TR, Holden EP, Christman BW, Christman JW: In vivo antioxidant treatment suppresses nuclear factor- $\kappa \mathrm{B}$ activation and neutrophilic lung inflammation. J Immuno/ 1996, 157:1630-1637.

21. Haddad JJE, Olver RE, Land SC: Antioxidant/Pro-oxidant equilibrium regulates HIF- $1 \alpha$ and NF- $\kappa$ B redox sensitivity: evidence for inhibition by glutathione oxidation in alveolar epithelial cells. J Biol Chem 2000, 275:21130-21139.

22. Sanlioglu S, Williams CM, Samavati L, Butler NS, Wang G, McCray PB Jr, Ritchie TC, Hunninghake GW, Zandi E, Engelhardt JF: Lipopolysaccharide induces Rac1-dependent reactive oxygen species formation and coordinates tumor necrosis factor- $\alpha$ secretion through IKK regulation of NF- $\kappa$ B. J Biol Chem 2001, 276:30188-30198.

23. Rocksén D, Ekstrand-Hammarström B, Johansson L, Bucht A: Vitamin E reduces transendothelial migration of neutrophils and prevents lung injury in endotoxin-induced airway inflammation. Am J Respir Cell Mol Biol 2003, 28:199-207.

24. Gorąca A, Józefowicz-Okonkwo G: Protective effect of an early treatment with lipoic acid in LPS-induced lung injury in rats. J Physiol Pharmacol 2007, 58:541-549.

25. Ritter C, da Cunha AA, Echer IC, Andrades M, Reinke A, Lucchiari N, Rocha J, Streck EL, Menna-Barreto S, Moreira JCF, Dal-Pizzol F: Effects of Nacetylcysteine plus deferoxamine in lipopolysaccharide-induced acute lung injury in the rat. Crit Care Med 2006, 34:471-477.

26. Aruoma Ol, Halliwell B, Hoey BM, Butler J: The antioxidant action of taurine, hypotaurine and their metabolic precursors. Biochem J 1988, 256:251-255
27. Hanna J, Chahine R, Aftimos G, Nader M, Mounayar A, Esseily F, Chamat S: Protective effect of taurine against free radicals damage in the rat myocardium. Exp Toxicol Pathol 2004, 56:189-194.

28. Roysommuti S, Azuma J, Takahashi K, Schaffer S: Taurine cytoprotection: from cell to system. J Physiol Sci 2003, 16:17-27.

29. Jeon SH, Lee MY, Rahman MM, Kim GB, Park SY, Hong CU, Kim SZ, Kim JS Kang HS: The antioxidant, taurine reduced lipopoylsaccharide (LPS)induced generation of ROS and activation of MAPKs and Bax in cultured pneumocytes. Pulm Pharmacol Ther 2009, 22:562-566.

30. Schuller-Levis G, Quinn MR, Wright C, Park E: Taurine protects against oxidant-induced lung injury: possible mechanism(s) of action. Adv Exp Med Biol 1994, 359:31-39.

31. Bhavsar T, Cantor JO, Patel SN, Lau-Cam CA: Attenuating effect of taurine on lipopolysaccharide-induced acute lung injury in hamsters. Pharmacol Res 2009, 60:418-428

32. Buege JA, Aust SD: Microsomal lipid peroxidation. Meth Enzymol 1978, 52:302-10.

33. Ellman GL: Tissue sulfhydryl groups. Arch Biochem Biophys 1959, 82:70-77.

34. Aebi H: Catalase in vitro. Meth Enzymol 1984, 105:121-126.

35. Günzler WA, Flohé L: Assay of glutathione peroxidase. Handbook of Methods for Oxygen Radical Research CRC PressGreenwald RE. Boca Raton, FL 1986, 285-290.

36. Ukeda H, Maeda S, Ishii T, Sawamura M: Spectrophotometric assay of superoxide dismutase based on tetrazolium salt $3^{\prime}-\{[1$-(phenylamino)carbonyl]-3,4-tetrazolium\}bis(4-methoxy-6-nitro)benzenesulfonic acid hydrate reduction by xanthine-xanthine oxidase. Anal Biochem 1997, 251:206-209.

37. Szarka RJ, Wang N, Gordon L, Nation PN, Smith RH: A murine model of pulmonary damage induced by lipopolysaccharide via intranasal instillation. J Immunol Methods 1997, 202:49-57.

38. Matute-Bello G, Frevert CW, Martin TR: Animal models of acute lung injury. Am J Physiol Lung Cell Mol Physiol 2008, 295:L379-L399.

39. Skerrett SJ, Liggitt HD, Hajjar AM, Ernst RK, Miller SI, Wilson CB: Respiratory epithelial cells regulate lung inflammation in response to inhaled endotoxin. Am J Physiol Lung Cell Mol Physiol 2004, 287:L143-L152.

40. Cui $X$, Hawari F, Alsaaty S, Lawrence $M$, Combs CA, Geng W, Rouhani FN, Miskinis D, Levine SJ: Identification of ARTS-1 as a novel TNFR1-binding protein that promotes TNFR1 ectodomain shedding. J Clin Invest 2002, 110:515-526

41. Micheau O, Tschopp J: Induction of TNF receptor I-mediated apoptosis via two sequential signaling complexes. Cell 2003, 114:181-190.

42. Maitra U, Singh N, Gan L, Ringwood L, Liwu L: IRAK-1 contribution to LPSinduced ROS generation in macrophages by inducing NOX-1 transcription, Rac1 activation, and suppressing the expression of antioxidative enzymes. J Biol Chem 2009, 284:35403-35411.

43. Balkan J, Parldar FH, Doğru-Abbasoğlu S, Aykaç-Toker G, Uysal M: The effect of taurine or betaine pretreatment on hepatotoxicity and prooxidant status induced by lipopolysaccharide treatment in the liver of rats. Eur J Gastroenterol Hepatol 2005, 17:917-921.

44. Lenz AG, Jorens PG, Meyer B, De Backer W, Van Overveld F, Bossart L, Maier KL: Oxidatively modified proteins in bronchoalveolar lavage fluid of patients with ARDS and patients at risk for ARDS. Eur Respir J 1999, 13:169-174.

45. Takano H, Inoue K, Yanagisawa R, Sato M, Shimada A, Morita T, Sawada M, Nakamura K, Sanbongi C, Yoshikawa T: Protective role of metallothionein in acute lung injury induced by bacterial endotoxin. Thorax 2004, 59:1057-1062.

46. Gorąca A, Aslanowicz-Antkowiak K: Prophylaxis with $\alpha$-lipoic acid against lipopolysaccharide-induced brain injury in rats. Arch Immunol Ther Exp (Warsz.) 2009, 57:141-146

47. Goraca A, Piechota A, Huk-Kolega H: Effect of alpha-lipoic acid on LPSinduced oxidative stress in the heart. J Physiol Pharmacol 2009, 60:61-68.

48. Mitsopoulos P, Omri A, Alipour M, Vermeulen N, Smith MG, Suntres ZE: Effectiveness of liposomal-N-acetylcysteine against LPS-induced lung injuries in rodents. Int J Pharm 2008, 363:106-111.

49. Balkan J, Kanbağli O, Aykaç-Toker G, Uysal M: Taurine treatment reduces hepatic lipids and oxidative stress in chronically ethanol-treated rats. Biol Pharm Bull 2002, 25:1231-1233.

50. Di Leo MA, Santini SA, Cercone S, Lepore D, Gentiloni Silveri N, Caputo S, Greco AV, Giardina B, Franconi F, Ghirlanda G: Chronic taurine 
supplementation ameloriates oxidative stress and $\mathrm{Na}^{+} \mathrm{K}^{+}$ATPase impairment in the retina of diabetic rats. Amino Acids 2002, 23:401-406.

51. Di Leo MAS, Ghirlanda G, Gentiloni Silveri N, Giardina B, Franconi F, Santini SA: Potential therapeutic effect of antioxidants in experimental diabetic retina: a comparison between chronic taurine and vitamin $\mathrm{E}$ plus selenium supplementation. Free Radic Res 2003, 37:323-330.

52. Giriş $M$, Depboylu B, Doğru-Abbasoğlu S, Erbil Y, Olgaç V, Aliş H, AykaçToker G, Uysal M: Effect of taurine on oxidative stress and apoptosisrelated protein expression in trinitrobenzene sulphonic acid-induced colitis. Clin Exp Immunol 2008, 152:102-110.

53. Oudit GY, Trivieri MG, Khaper N, Husain T, Wilson GJ, Liu P, Sole MJ, Bachx PH: Taurine supplementation reduces oxidative stress and improves cardiovascular function in an iron -overload murine model. Circulation 2004, 109:1877-1885.

54. Gong H, He J, Lee JH, Mallick E, Gao X, Li S, Homanics GE, Xie W: Activation of the liver $X$ receptor prevents lipopolysaccharide-induced lung injury. J Biol Chem 2009, 284:30113-30121.

55. Yoshikawa T, Takano H, Takahashi S, Ichikawa H, Kondo M: Changes in tissue antioxidant enzyme activities and lipid peroxides in endotoxininduced multiple organ failure. Circ Shock 1994, 42:53-58.

56. Carter JM, Corson N, Driscoll KE, Elder A, Finkelstein JN, Harkema JN, Gelein R, Wade-Mercer P, Nguyen K, Oberdoster G: A comparative doserelated response of several key pro- and anti-inflammatory mediators in the lungs of rats, mice and hamsters after subchronic inhalation of carbon black. J Occup Environ Med 2006, 48:1265-1278.

57. Dirami G, Massaro D, Clerch LB: Regulation of lung manganese superoxide dismutase: species variation in response to lipopolysaccharide. Am J Physiol Lung Cell Mol Physiol 1999, 276:L705-L708.

58. Duke SS, Bolds JM, Lloyd JE, Brigham KL: Endotoxin-induced neutrophilic alveolitis and macrophage chemotaxin production in sheep. Am J Med Sci 1988, 296:381-386.

59. Liu Y, Quinn MR: Chemokine production by rat alveolar macrophages is inhibited by taurine chloramine. Immunol Lett 2002, 80:27-32.

60. Marcinkiewicz J: Neutrophil chloramines: missing links between innate and acquired immunity. Immunol Today 1997, 18:577-580.

61. Marcinkiewicz J, Grabowska A, Beretta J, Bryniarski K, Nowak B: Taurine chloramine down-regulates the generation of murine neutrophil inflammatory mediators. Immunopharmacology 1998, 40:27-38.

62. Park E, Jia J, Quinn MR, Schuller-Levis G: Taurine chloramine inhibits lymphocyte proliferation and decreases cytokine production in activated human leukocytes. Clin Immunol 2002, 102(2):179-84.

63. Chorąży M, Kontny E, Marcinkiewicz J, Maśliński W: Taurine chloramine modulates cytokine production by human blood mononuclear cells. Amino Acids 2002, 23:407-413.

64. Martinez-Losa M, Cortijo J, Piqueras L, Sanz MJ, Morcillo EJ: Taurine chloramine inhibits functional responses of human eosinophils in vitro. Clin Exp Allergy 2009, 39:537-546.

65. Marcinkiewicz J, Grabowska A, Bereta J, Bryniarski K, Stelmaszynska T: Taurine chloramine, a product of activated neutrophils, inhibits in vitro the generation of nitric oxide and other macrophage inflammatory mediators. J Leukocyte Biol 1995, 58:667-674.

66. Redmond HP, Stapleton PP, Neary P, Bouchier-Hayes D: Immunonutrition: the role of taurine. Nutrition 1998, 14:599-604.

67. Wei S-M, Yan Z-Z, Zhou J: Taurine reduces testicular ischemia/ reperfusion-induced neutrophil recruitment to testis probably by downregulation of pro-inflammatory cytokines and E-selectin. Urology 2008, 72:464-465.

68. Park E, Alberti J, Quinn MR, Schuller-Levis G: Taurine chloramine inhibits the production of superoxide anion, IL-6, and IL-8 in activated human polymorphonuclear leukocytes. Adv Exp Med Biol 1998, 442:177-182.

69. Miyamoto Y, Kanayama A, Inoue J, Konishi YS, Shimizu M: Taurine is involved in oxidation of $\mathrm{I} \kappa \mathrm{B} \alpha$ at Met45: $\mathrm{N}$-halogenated taurine and antiinflammatory action. Adv Exp Med Biol. 2003, 526:373-80.

70. Egan BM, Chen G, Kelly CJ, Bouchier-Hayes DJ: Taurine attenuates LPSinduced rolling and adhesion in rat microcirculation. J Surg Res 2001, 95:85-91.

71. Klamt F, Schacter E: Taurine chloramine, an oxidant derived from neutrophils, induces apoptosis in human B lymphoma cells through mitochondrial damage. J Biol Chem 2005, 280:21346-21352.
doi:10.1186/1423-0127-17-S1-S19

Cite this article as: Bhavsar et al:: Protective action of taurine, given as a pretreatment or as a posttreatment, against endotoxin-induced acute lung inflammation in hamsters. Journal of Biomedical Science 201017 (Suppl 1):S19.

\section{Submit your next manuscript to BioMed Central and take full advantage of:}

- Convenient online submission

- Thorough peer review

- No space constraints or color figure charges

- Immediate publication on acceptance

- Inclusion in PubMed, CAS, Scopus and Google Scholar

- Research which is freely available for redistribution

Submit your manuscript at www.biomedcentral.com/submit 